\title{
ФРАНКОМОВНА МЕДИЧНА ТЕРМІНОЛОГІЯ: \\ СТРУКТУРНИЙ, СЕМАНТИЧНИЙ \\ І ПЕРЕКЛАДАЦЬКИЙ АСПЕКТИ
}

\author{
Бондар Л. В., Школяр Л. В.
}

\section{ВСТУП}

3 огляду на поглиблення міжнародних зв'язків України з франкомовними державами в різних сферах суспільного життя, зокрема розширення франко-української співпраці в медичній і фармацевтичній галузі (функціонування асоціацій, французьких фармацевтичних компаній на території України), i, відповідно, на потреби ринку праці, постає необхідність проведення наукових пошуків, присвячених питанню дослідження фахової міжкультурної комунікації, виявлення передумов та ефективних підходів до здійснення галузевого перекладу.

Дослідження мовних особливостей франкомовних медичних текстів дає змогу розуміти й інтерпретувати структурні, мовні, стилістичні особливості текстів різних жанрів медичної та фармацевтичної галузі, оперувати необхідною термінологією, оволодіти фоновою інформацією як системою знань у галузі медицини та фармації, що є важливою передумовою здійснення адекватного перекладу фахових текстів. Отже, аналіз лінгвістичних характеристик франкомовних медичних текстів $\epsilon$ передумовою успішної реалізації міжкультурної взаємодії між представниками наукових i професійних спільнот, а оволодіння вміннями перекладу медичних і фармацевтичних текстів різних жанрів розширює можливості філолога стати конкурентоспроможним фахівцем міжнародного рівня.

Питання дослідження жанрово-стилістичних особливостей текстів медичної та фармацевтичної галузі, їх структурних, мовних, комунікативно-прагматичних характеристик і засобів їх відтворення в процесі перекладу перебували в центрі уваги низки дослідників, зокрема Н. Васильєва, І. Данілова та Ю. Данілова, Н. Подольська, В. Марченко, А. Реформатський, А. Суперанська присвятили наукові пошуки проблемі вивчення термінологічних одиниць, А. Боцман, Г. Бурова, К. Макеєв аналізували особливості іншомовних фармацевтичних текстів з погляду різних аспектів, С. Вострова окреслила лінгвокогнітивні та комунікативно-прагматичні характеристики сучасного англомовного медичного дискурсу, С. Барбазева визначила особливості перекладу 
абревіатур в англомовному медичному тексті, Т. Смельянова здійснила аналіз структурних і семантичних особливостей французьких медичних термінів-фразеологізмів латинського походження, С. Мишланова досліджувала явище метафоризації лексики в науково-популярному дискурсі, Є. Солнцев здійснив аналіз потенційних труднощів перекладу медичних текстів.

Незважаючи на низку праць, у яких активно осмислена зазначена проблематика, питання відтворення мовних особливостей медичних франкомовних текстів в українському перекладі залишається невирішеним. Отже, стан дослідження зазначеного питання обгрунтовує актуальність подальших наукових пошуків, зумовлених загальною спрямованістю сучасних мовознавчих студій на комплексне дослідження мовних явищ у взаємодії їх прагматичних, структурних, семантичних і перекладацького аспектів.

Низка проблем, що виникають у процесі перекладу медичних текстів, має загальний характер, вони $є$ типовими й не пов'язані зі специфікою мови оригіналу та цільової мови, головним чином це стосується рівня термінологічних одиниць, як-от: явище синонімії термінів, наявність епонімів, скорочень. У свою чергу, потенційні труднощі граматичного, стилістичного, комунікативно-прагматичного аспектів мають специфічний характер залежно від мовних пар, систем та узусу зіставлюваних мов ${ }^{1}$.

Метою наукових розвідок $\epsilon$ визначення структурно-семантичних характеристик франкомовних медичних термінів i засобів їx відтворення в українському перекладі.

\section{1. Франкомовна медична термінологія як об'єкт лінгвістичного дослідження}

Особливостями лексико-семантичного рівня текстів науковотехнічної літератури, медичної галузі зокрема $\epsilon$ їх насиченість спеціальною термінологією, характерними лексичними конструкціями, скороченнями та абревіатурами ${ }^{2}$. Медичні терміни характеризуються стилістичною нейтральністю, наявністю дефініції, стислістю, точністю семантики, тому для інтерпретації їх значення контекст не $\epsilon$ обов'язковою умовою, оскільки сама терміносистема і $\epsilon$ контекстом.

\footnotetext{
${ }^{1}$ Солнцев Е.М. Перевод медицинских текстов: к вопросу о соотношении общих и частных проблем. Москва : ИПК МГЛУ «Рема», 2010. URL: http: // www.thinkaloud.ru/science/solnts-med.pdf (дата звернення: 25.08.2020).

2 Деркач Л.М. Актуальні проблеми науково-технічного перекладу. Донецьк : Національний гірничий ун-т, 2007. 257 с.
} 
Однак у певних випадках поза межами терміносистеми лексична одиниця може втрачати зазначені характеристики у зв'язку з можливою синонімією, омонімією, наявністю термінів-епонімів, у такому разі термін варто аналізувати в контексті, відповідно до якого цей термін несе своє семантичне навантаження, а не як ізольовану одиницю, значення якої може змінюватися залежно від галузі, у якій вона функціонує.

Під мовою медицини розуміється набір мовних одиниць, за допомогою яких фахівці можуть вести комунікацію професійної спрямованості ${ }^{3}$. Медична термінологія є одним зі специфічних прошарків лексики, який у силу особливостей структурно-семантичного, словотвірного і стилістичного характеру відрізняється від загальновживаних слів і тим самим займає особливе місце в лексичній системі мови ${ }^{4}$.

Класифікаційний підхід до вивчення термінів допомагає наочно продемонструвати термінологічну парадигму певної предметної галузі, відображаючи ієрархію зв'язків між ії елементами на основі низки виділених ознак. Формальні кордони певного терміна прямо залежать від його змістового навантаження. У межах медичної термінології можна виокремити три групи, поділ на які здійснюється відповідно до сфери застосування та характеристик об'єкта, для позначення якого вони використовуються.

До першої групи належать загальнонаукові терміни, які утворюють загальний поняттєвий фонд різних наук ( $f$ loi, $m$ appareil, $f$ réaction, $f$ déduction, fréduction, $m$ paradigme, $f$ ambiguïté etc.): La taille, la forme et la structure des cellules de l'organisme humain ou animal sont d'aspect très variable, ce qui est en rapport avec la spécificité fonctionnelle des cellules 5 .

Друга група представлена міжгалузевими термінами, використання яких не обмежується однією галуззю знань ( lame, $f$ amortisation): Les mitochondries à crêtes typiques, de forme longue et incurvée, avec une matrice dense aux électrons, elles sont alignées le long de la membrane cellulaire bordant un espace intercellulaire. La cellule glandulaire avec des grains de sécrétion de glande lacrymale humaine ${ }^{6}$.

${ }^{3}$ Ильина Н.В. Особенности перевода медицинской терминологии. Методологія та практика лінгвістичної підготовки іноземних студентів : збірник матеріалів Міжвузівської науково-практичної конференції (18 квітня 2012 р.). Харків : ХНМУ, 2012. C. $67-68$

${ }^{4}$ Синельников Ю.Г., Подорванова Я.С. Метафора как средство образования медицинских терминов (на материале французской прессы). Научные ведомости Белгородского гос. ун-та. Серия «Гуманитарные науки». 2014. № 6 (177). Вып. 21. C. 116-121.

5 Kühnel W. Atlas de poche d'histologie: Cytologie, histologie et anatomie microscopique. Paris : Edition Flammarion, 2003. P. 2.

${ }^{6}$ Там само. С. 32. 
До третьої групи входять вузькоспеціалізовані терміни, які слугують для позначення понять, що є відображенням специфіки певної галузі (le thorax, m eodem, $m$ naevus): Les motoneurones de la corne antérieure de la moelle épinière (columna anterior de la medulla spinalis), ont été obtenus après discrète macération de la moelle, étalement et colorations. Les cellules ganglionnaires sont entourées d'une capsule et cellules gliales, les cellules du manteau ou cellules satellites ${ }^{7}$.

Базуючись на такому критерії як об'єкт найменування, медичні терміни можна об'єднати в лексико-семантичні групи, які дають змогу виділити такі термінологічні підсистеми:

- анатомічна, що містить терміни на позначення складових організму людини, його органів і систем (m membre inférieur, $m$ poumon, $m$ crâne, $m$ cerveau, $m$ foie, $f$ moelle, $f$ rate, $m$ pancréas, $m$ pl reins, $f$ cavité buccale, f mâchoire, $m$ tronc, $m$ diaphragme, f colonne vertébrale, $m$ rectum, système nerveux);

- клінічна, до якої входять назви захворювань і їх симптоматика (f névralgie, $f$ fracture de la cuisse, $f$ hernie de la fente de Larrey, fasphyxie, $m$ cancer, $f$ hépatite, $f$ gastroentérite à rotavirus, $f$ acromégalie, f néoplasie rare);

- назви медичних приладів і методів обстеження (m appareil d'Ombrédanne, $m$ tensiomètre, $f$ tomodensitométrie, fmammoghraphie, fradiographie, fméthode de Holter, $m$ cytodiagnostic urinaire sur culot, m capnomètre);

- адміністративна, що охоплює лексичні одиниці на позначення медичної документації ( $f$ nosographie, $m$ dossier médical, $m$ dossier $d u$ malade, $m$ dossier administratif et social, $f$ histoire santé $d u$ patient, $f$ carte d'informations iconiques, $f$ fiche de recueil d'information, $f$ fiche médicale ambulatoire);

- фармацевтична, яка відображає назви хімічних речовин, лікарських засобів, діючих речовин ( $m$ magnesium, $m$ diclofénac, $m$ calcium, foxomémazine, $m$ acétaminophène, $m$ naproxène, $m$ fluoro-uracile, $m$ docétaxel, fdoxorubicine, f antrhacicline, $m$ inhibiteur de la pompe à protons).

Остання підсистема може бути поділені на такі підгрупи термінів:

- лексичні одиниці на позначення хімічної природи лікарської речовини та іiі концентрації ( $m$ potassium, $f$ solution concentrée d'hypochlorite de sodium, $m$ hexachlorocyclohexane, $m$ valsartan, f digoxine);

- терміни, значення яких відображають фізичний стан ліків, форму лікарського препарату тощо ( $m$ sirop, $f$ gélule, $f$ pl gouttes, $f$ pl pastilles, $m$ comprimé, $m$ sachet, fforme galénique, $f$ pommade);

${ }^{7}$ Там само. С. 2. 
- терміни на позначення допоміжних речовин, їх природи, фізичного стану, концентрації ( $m$ excipient, $m$ colorant, $m$ conservateur, $m$ saccharose, $m$ fer rouge oxyde, $m$ amidon prégélatinisé, $m$ polysorbate 80 , $m$ cire d'abeille blanche, $m$ p-hydroxybenzoate de propyle, $m$ sodium benzoate);

- терміни на позначення шляхів уведення лікарських засобів ( $f$ injection intraveineuse, $f$ injection sous-cutanée, $f$ injection intramusculaire, $f$ inhalation, $f$ absorption, $f$ voie nasale, $f$ voie perlinguale, $f$ voie auriculaire);

- терміни на позначення фармацевтичних технологій та обладнання, що застосовуються у виробництві ( $m$ centrifuge).

Варто зазначити, що різні жанри медичних i фармацевтичних текстів оперують термінами різної складності, оскільки вибір лексичних одиниць залежить від мети документа й комунікативнопрагматичного наміру автора, а також його спрямованості на певного реципієнта - пацієнта чи фахівця медичної галузі.

Специфіка наукових термінів вимагає дотримання певних правил при утворенні термінологічних одиниць, що корелює з універсальністю терміна: він відображає й поняттєву парадигму фундаментальних наук, призначений забезпечувати запити професійної комунікації, а отже, він має бути прозорим, точним, унормованим ${ }^{8}$.

Франкомовні терміни медичної галузі утвоюються за традиційними словотворчими моделями, поява нового терміна може бути також зумовлена семантичним розвитком лексичної одиниці загальновживаної лексики шляхом метафоризації та збагачення чи звуження поняття, десемантизації. Відповідно до формальноструктурних характеристик, терміни можна поділити на:

- прості (f leucémie, flipodystrophie, $m$ lymphome, fostéogénèse): Ces concrétions sont constituées d'une matrice organique imprégnée de sels de calcium et de magnésium. Les thrombocytes sont les éléments cellulaires les plus petits entrant dans la constitution du sang ${ }^{9}$;

- складні, що поєднують дві чи більше основ ( $m$ adénocarcénome, flymphoprolifération): La pseudomultistratification de l'épithélium du pli vestibulaire du larynx est beaucoup plus marquée que celle en épithélium cylindrique $^{10}$;

8 Ракшанова Г.Ф. Система дериваційних засобів сучасної науково-технічної термінології (когнітивно-номінативний аспект : автореф. дис. ... канд. філол. наук : 10.02.01 «Українська мова». Київ, 2004. С. 16.

9 Kühnel W. Atlas de poche d'histologie: Cytologie, histologie et anatomie microscopique. Paris : Edition Flammarion, 2003. P. 232.

${ }^{10}$ Там само. C. 82. 
- складені, що містять дві чи більше сполуки, які пишуться окремо ( $m$ carcinome hépatocellulaire, $f$ acide delta-aminolévulinique, $m$ chimiquement pur état homogène, $f$ réponse au traitement par anticorps monoclonaux, $f$ rétine tachetée familiale bénigne, $f$ rétraction congénitale des paupières, $m$ nanisme géléophysique, $f$ naissance de l'artère coronaire gauche à partir du sinus droit): La surface de la glande surrénale est entourée d'une capsule conjonctive fibreuse, celle-ci est recouverte de tissu conjonctif lâche, vascularisé, riche en adipocytes ${ }^{11}$.

\section{2. Франкомовні синтетичні терміни медичної галузі: структурно-семантичні особливості й засоби їх відтворення} в українському перекладі

Однокомпонентні терміни $є$ синтетичними одиницями, які можуть бути утворені шляхом суфіксації, префіксації, парасинтезу (суфіксально-префіксальним способом), конверсії, основоскладання; виділяють також терміни-гібриди, що складаються з терміноелементів двох мов (арабо-грец. alcalose f), терміни-абревіатури.

С. Грінев-Гріневич використовує поняття «похідних» термінів для позначення лексичних одиниць, утворених синтетичним (морфологічним) способом, наголошуючи на тому, що вони 3'явилися саме завдяки різноманітним морфологічним засобам творення ${ }^{12}$. Найпродуктивнішими морфологічними способами термінотворення в межах французької медичної галузі є суфіксація та основоскладання.

Вагома частка термінів має в складі елементи (афікси та кореневі морфеми) латинського та грецького походження (див. таблиця 1), тому усвідомлення етимології слова є важливою передумовою, що впливає на ефективність перекладу фахових текстів ${ }^{13}$.

Серед найпоширеніших суфіксів, які володіють дериваційним потенціалом, можна назвати такі: -ite, -isme, -ence, -ure, -tien, -iste etc., зокрема суфікси -tion, (s)sion, -ation позначають стан, дію та результативність: $f$ propagation, f concrétition; -ite - відтворюють назви явищ, що корелюють із поняттям запалення: $f$ mastite, $f$ colite, $f$ nephrite, $f$ tendinite, $f$ conjonctivite, $f$ arthrite, $f$ appendicite, $f$ bronchite ; -eur, -teur позначають виконувача дії або певну характеристику - $\mathrm{m}$ médiateur, $m$ bronchodilatateur; -té позначає здатність і здібність: f capillarité, суфікс isme відтворює назву хвороби чи симптому: $m$ nanisme, $m$ anévrisme, $m$

11 Kühnel W. Atlas de poche d'histologie: Cytologie, histologie et anatomie microscopique. Paris : Edition Flammarion, 2003. P. 258.

12 Гринев-Гриневич С.В. Терминоведение. Москва : Издательский центр «Академия», 2008. С. 60.

13 Полюк І.С., Бондар Л.В. Особливості перекладу текстів різних стилів. Французька мова. Київ : НТУУ «КПІ», 2011. С. 15. 
météorisme, $m$ botulisme, $m$ hyperthyrö̈disme. Суфікс -ine, -ïne найчастіше вживається для творення термінів на позначення хімічних речовин, які входять до складу медичних препаратів чи ті, які використовують для їх приготування, а також на позначення білків: fantitrypsine; flécithine, f allantoïne.

Таблиця 1

Греко-латинські елементи ї̈х значення в складі медичних термінів

\begin{tabular}{|c|c|c|}
\hline Élément & Signification & Exemple \\
\hline andro & homme, mâle & Androgène \\
\hline antho & fleur & Anthophile \\
\hline bio & vie & Biocénose \\
\hline carpo & fruit & Carpophore \\
\hline chromo (chomato) & couleur & Chromosome \\
\hline cryo & froid & Cryogène \\
\hline cyto & cellule & Cytochimie \\
\hline cata & vers le bas, achèvement & Catabolisme \\
\hline glyc(o) & sucre & Glycémie \\
\hline gyno (gyn-) & femme, femelle & Gynarchie \\
\hline héma (hémato) & sang & Hématorrhée \\
\hline $\operatorname{lip}(0)$ & graisse & Lipoïde \\
\hline lys(o) & $\begin{array}{l}\text { décompositbn, } \\
\text { destruction }\end{array}$ & Hydrolyse \\
\hline mér(o) & partie & Mérotomie \\
\hline $\operatorname{morph}(\mathrm{o})$ & forme & Morphologie \\
\hline my(o) & muscle & Myologie \\
\hline oo (ovi) & œuf & oosphère ovipare \\
\hline photo & lumière & Phototrophe \\
\hline phyl(o) & tribu, lignée & Phylogenèse \\
\hline phyll(o) & feuille & Phyllotaxie \\
\hline physi(o) & nature & Physique \\
\hline phyto & plante & Phytocénose \\
\hline télo (téléo) & fin & Téiophase \\
\hline tropho & nourriture & Trophocyte \\
\hline ultra & au dela & Ultrason \\
\hline
\end{tabular}


Суфікс латинського походженя -cide має значення «celui qui tue», тому він зустрічається в термінах на позначення речовин для найменування препаратів для боротьби із симптомами хвороби, 3 вірусною, бактеріальною, грибковою інфекціями: bactéricide, antiacide. Значна кількість термінів утворена за допомогою суфікса -ie, який уживається для вираження якості предмета чи дії, а також на позначення самої дії: facathésie, fanésthésie.

Дещо меншим рівнем продуктивності володіють такі суфікси: -pathie, що походить із грецької мови й означає «хворобливий стан», тому зустрічається в термінах на позначення симптомів хвороби або самої хвороби: $f$ kérathopathie, $f$ myopathie,f hémopathie, fostéopathie, $f$ psychopathie, $f$ neuropathie, $f$ angiopathie. Суфікс -bie має значення «живий», тобто вживається для позначення кореляції певного поняття чи явища із живими організмами: faérobie, -ectasie - розширення, дилатація: $f$ bronchectasie, -ectomie - оперативне видалення: fmastectomie, fadénomectomie.

Суфікс -ѐnе зустрічається в складі іменників і в прикметників, він відтворює значення найменування препаратів, речовин, гормонів і характеристики певних засобів і симптомів тощо: f adapalène, algogène.

У більшості випадків при перекладі термінів, утворених суфіксацією, використовують семантичний еквівалент, український відповідник, при цьому, наприклад: суфікс -ité відповідає українському -icmb, суфікс -ation відтворюється за допомогою афікса -ання -eur -op, ie - ія тощо: $f$ absorption - абсорбиія, всмоктування, $f$ réduction редукиія, зменшення. У процесі відтворення значення зазначених термінів (особливо лексичних одиниць греко-латинського походження) варто враховувати особистість потенційного адресата: якщо текст призначений для пацієнтів, то зазвичай застосовується український відповідник ( $f$ anémie - недокрів'я, $f$ paramnésie - розлад пам'яті), для фахівців медичної галузі - інтернаціональний відповідник ( $f$ anémie анемія, $f$ paramnésie - парамнезія, $f$ ascite - асцит), термін може бути відтворений шляхом транслітерації або калькування чи за допомогою описового перекладу: $f$ estérification - перетворення в складний ефip; $f$ décantation - декантачія рідини, $f$ endométrite - запалення слизової оболонки матки, $f$ perturbation - розлад функцій органів, $f$ ascite водянка черевної порожнини.

Поширеним способом формування синтетичних термінів $\epsilon$ префіксація, що відбувається за допомогою таких префіксів: super-, supra-, sur-, dé-, anti-, trans-, re-, micro-, alb-, aur-, aut-, archi-, corтощо, кожен із яких має своє семантичне навантаження, наприклад: super-, supra-, sur- мають значення надмірності, перебільшення або вказують на поверхневість: $f$ superficie, $m$ surfactant ; 
dé- використовується для утворення термінів на позначення протилежної негативної дії: $f$ déshydratation, anti- позначає протилежне поняття або препарат для лікування якогось захворювання: antidiabétique, $m$ anticorps, antipsychotique, apo- позбавлений, відділений від: fapoptose, ana- повернення, повторення: fanaplasie, trans- через: translucide, hémi- половина: $m$ hémisphère cérébral, albпов'язаний із білим кольором: $m$ albinos, oligo- вказує на невелику кількість будь-чого, на відхилення від норми в бік зменшення: m oligosaprobies, $m$ oligophénylène.

Парасинтез, тобто афіксальний спосіб словотворення, відображається в поєднанні двох зазначених вище синтетичних способів словотворення префіксації та суфіксації (préfixe + base+ suffixe): $f$ dyspepsie (dys: порушення, pepsie: травлення), $m$ biocatalyseur, $f$ transpiration, fexophtalmie, $f$ épisiotomie, $f$ intoxication. У процесі перекладу термінів, утворених шляхом префіксації та парасинтезу, найчастіше вдаються до пошуку семантичного еквівалента, транслітерації та калькування, що зазвичай не змінює їх структуру: $f$ biofiltration - біофільтрація, antidiabétique - антидіабетичний, $m$ microtubule - мікротрубочка. Можливий також варіант застосування описового перекладу: m décongestionnant - той, щзо зменшує прилив крові.

Іншим важливим типом синтетичного термінотворення медичних лексичних одиниць $є$ основоскладання, у цьому випадку в складі однослівного терміна знаходиться дві чи більше кореневих морфем (m ganglioneuroblastome, $f$ gastroparésie, $f$ glomérulonéphrite, $m$ biosimilaire): La neurohypophyse comprend le lobe postérieur et l'infundibulum avec l'éminence médiane. L'épiphyse est un organe de forme conique, recouvert par la pie-mère. Les lobules sont constitués de pinéalocytes (cellules photoréceptrices modifiées), de cellules interstitielles, disposés souvent en cordons ou amas cellulaires d'allure épithéliale, et de cellules gliales (astrocytes) ${ }^{14}$.

Серед термінів, утворених зазначеним способом, значну частку становлять також лексичні одиниці, що складаються 3 греколатинських морфем, які зазвичай об'єднуються, формуючи нове поняття: f pyrolyse, finsulinase, féstérase. У процесі відтворення значень франкомовних термінів українською мовою найчастіше вдаються до пошуку відповідника, до калькування чи описового перекладу: $f$ cardionévrose - кардіоневроз, або нейрочиркуляторна дистонія; $m$ glycosaminoglycane - глікозамінглікан, ftétraiodothyronine тетрайодтіронін.

14 Kühnel W. Atlas de poche d'histologie: Cytologie, histologie et anatomie microscopique. Paris : Edition Flammarion, 2003. P. 256. 
У процесі термінотворення спостерігається також явище конверсії, яке полягає в переході однієї частини мови в іншу зі зміною своєї синтаксичної функції та категоріальної семантики. Так, при конверсії прикметника в іменник конвертоване слово отримує значення ознаки предмета. Зберігається один і той же фонетичний (і графічний) вигляд у вихідного й у конвертованого слова: androgène (adj) - un androgène(s); acidiphile (adj) - une acidiphile (s); allélomorphe (adj) - un allélomorphe (s); pyrogène (m; adj.) - nірогенний - піроген: для перекладу прикметника пірогенний використовується еквівалент, а для іменника - транслітерація.

До морфологічних засобів творення нових термінологічних одиниць також зараховують абревіацію: (OPN - os propres $d u$ nez, AHU Assistant Hospitalier Universitaire, ESF - Étudiant Sage-Femme, IFMEM Institut de Formation de Manipulateur d'Electrocardiologie Médicale).

Утворення скорочень у межах певної терміносистеми є наслідком появи нових явищ i процесів, пов'язаних із науково-технічним прогресом, реалізацією закону економії мовних засобів і прагнення до підвищення ефективності комунікативної функції мови. У французькій мові абревіатури мають однакову форму для множини й однини, а категорія числа реалізується за допомогою артиклів або інших детермінативів ${ }^{15}$.

Головними засобами відтворення значень французьких скорочень українською мовою $є$ :

- використання еквівалентного скорочення мови перекладу в разі його існування (PCC: $f$ pancréatite chronique calcifiante - ХКП хронічний кальиифікуючий панкреатит, IC: $f$ insuffisance cardiaque CH: сериева недостатність, $f$ ADN acide désoxyribonucléique - ДНК: дезиксорибонуклеїнова кислота, ДНК);

- транскрипція і транслітерація, до яких вдаються головним чином для передачі назв медичних і фармацевтичних установ, організацій, товариств, назв певних ферментів чи хвороб (LDH: Lactate deshydrogénase - ЛДГ: лактатдегідрогеназа);

- описовий переклад (ACFA: farythmie complète par fibrillation auriculaire - фібриляџія передсердь/миготлива аритмія, ANPA: Association nationale de prévention de l'alcoolisme - Національна асоиіація з попередження алкоголізму, MAR: Médecin anesthésisteréanimateur - лікар анестезіолог-реаніматолог);

- створення нового скорочення українською мовою (HDJ: Hôpital du jour - ДС: Денний стаціонар).

15 Полюк І.С., Бондар Л.В. Особливості перекладу текстів різних стилів. Французька мова. Київ : НТУУ «КПІ», 2011. С. 17. 
У текстах медичної галузі значну частку також становлять інтернаціональні скорочення, що походять головним чином із латинської мови (TID: ter in die-trois fois par jour-mричі на день, PRN: pro re nata - au besoin - y разі необхідності). Більшість із них у процесі відтворення залишається незмінною, якщо текст створений для фахівців медичної галузі, у певних же випадках вони можуть зазнавати перекладу, наприклад, у межах науково-популярних текстів, призначених для пересічних громадян ${ }^{16}$.

Однією зі значущих проблем перекладу абревіатур є їх омонімія, наприклад, САР має двадцять п'ять різних значень у межах різних галузей і лише одне значення в медичній (CAP: Centre d'accueil et de psychothérapie - иентр медико-соиіальної допомоги та психотерапіï).

Низка термінів-англіцизмів використовується як інтернаціональна абревіатура, яка в процесі використання розшифровується мовою перекладу, як-от англомовний акронім CIN: cervical intraepithelial neoplasia, $\phi p$. lésion précancéreuse du col utérin dépistée par les frottis cervico-utérins, укр. СІN(ЦІН): інтраепітеліальна цервікальна неоплазія; Rad: англомовна абревіатура від radiation absorbed dose; fr. $f$ dose de rayonnement absorbée, поглинута доза іонізуючого випромінювання;

Варто зазначити, що при перекладі медичних термінів важливу роль відіграє особистість потенційного адресата, що впливає на вибір перекладацьких стратегій, визначаючи, варто зберігати термінологічний характер лексичної одиниці та іiі прагматичне значення чи адаптувати термін для його сприймання й розуміння реципієнтом, що не $\epsilon$ фахівцем галузі охорони здоров'я.

\section{3. Структурно-семантичні особливості бінарних і багатокомпонентних франкомовних медичних термінів і засоби їх відтворення українською мовою}

Аналітичний спосіб творення термінів $є$ досить продуктивним і перспективним, оскільки він допомагає відобразити складний і багатоаспектний взаємозв'язок між явищами та поняттями наукової галузі. Багатокомпонентний термін допомагає більш повно й точно передати належність об'єкта до класифікаційного ряду, що грунтується на родових i видових співвідношеннях понять без додаткової експлікації ${ }^{17}$.

16 Могилевский Р.И. О некоторых специфических функциях аббревиатур. Пермь : Изд-во ПГУ, 1999. С. 60-64.

17 Марченко В.С. Основні способи термінотворення: (на матеріалі буд. термінології). Культура слова. 1980. Вип. 18. С. 36-40. 
Багатокомпонентні аналітичні терміни містять дві чи більше лексичних одиниць у своєму складі. Бінарні сполуки можна поділити, у свою чергу, на такі групи відповідно до характеристик їх компонентів:

- складники терміна є автономними елементами, кожен із яких зберігає своє лексичне значення незалежно від іншого компонента: ( $f$ cellules polygonales, $m$ glaucome congénital, $m$ giome nasal, $f$ glycinémie cétosique, $f$ hémoglobine glyquée, $f$ hernie discale): La corde vocale du larynx est revêtue d'un épithélium multistratifié pavimenteux non kératinisé et non déplaçable de son support ${ }^{18}$;

- словосполучення, які містять термінологічну одиницю та інший елемент, що $є$ загальновживаним словом, і в межах ізольованого вживання не є терміном: ( ramification artérielle, f insuffisance aortique, $m$ agent contaminateur, $f$ fente articulaire): On distingue deux types d'artères: les artères proches du coeur et les artères périphériques. La couche basale comporte des cellules prismatiques, seules elles reposent sur la membrane de Bowman ${ }^{19}$;

- два елементи словосполучення належать до загальної лексики, але в складі двохкомпонентної сполуки набувають термінологічного значення: ( $m$ membre inférieur, $f$ affection mentale, $m$ globule blanc): La paroi des artères et des veines comprend trois couches: la tunique interne ou intima, la tunique moyenne ou média et la tunique externe ou adventice ${ }^{20}$.

Найчисленнішу групу синтаксичних медичних термінів становлять двокомпонентні конструкції 3 підрядним зв'язком. У зазначених сполуках виділяють три типи семантико-синтаксичних зв'язків: атрибутивні, субстанціальні й адвербіальні (обставинні) ${ }^{21}$.

Для творення термінологічних словосполучень найпродуктивнішою $\epsilon$ атрибутивна модель Nom + Adjectif, у якій головний компонент позначає певне явище, поняття, а залежний елемент доповнює його значення певною ознакою: $f$ glucosurie rénale, $f$ panartérite noueuse, $f$ pancréatite tropicale, f pelade universelle, $m$ rétinoblastome hériditaire, $m$ catalyse enzymatique, f réaction analytique, f dermatoarthrite herpétiforme.

Іншою менш поширеною моделлю $є$ конструкція Nom + Nom: fglomérulopathie à lipoporotéines, $m$ glycogénose par déficit, $f$ diverticule $d u$ coeur, $f$ dysplasie en boomerang, $m$ traitement par adénomectomie, $m$ botulisme par inoculation, $f$ canalopathie avec épilepsie, $f$ oesophagite à

18 Kühnel W. Atlas de poche d'histologie: Cytologie, histologie et anatomie microscopique. Paris : Edition Flammarion, 2003. P. 86.

${ }^{19}$ Там само.

20 Kühnel W. Atlas de poche d'histologie: Cytologie, histologie et anatomie microscopique. Paris : Edition Flammarion, 2003. P. 6.

${ }^{21}$ Непийвода Н.Ф. Вираження атрибутивних відношень у терміні. Науковотехнічний прогрес і проблеми термінології : тези доп. респ. конф. Київ, 1980. С. 134. 
éosinophiles, $f$ campodacylie de Goodman, $f$ laminopathie avec lipodystrophie. Іменники в таких словосполученнях поєднуються, як правило, прийменниками $d e, \grave{a}, p a r, a v e c$, en тощо. Для утворення таких конструкцій можуть використовуватися як терміни, так і загальновживана лексика ${ }^{22}$.

Особливості перекладу двокомпонентних термінів зумовлюються головним чином їх структурно-семантичними характеристиками, зокрема термінологічні сполуки, утворені за моделлю Nom + Adjectif, відтворюються українською мовою за допомогою калькування без зміни складників, відбувається лише їх перестановка - у мові перекладу отримуємо комбінацію елементів Adjectif + Nom: f fente articulaire - суглобова щілина, $m$ agent antiviral - противірусний засіб.

В інших випадках можлива також зміна структури сполуки: m oxyde nitreux (Nom + Adjectif) - оксид азоту (Nom + Nom), заміна при перекладі бінарного терміна на простий: $\mathrm{m}$ trouble de l'audition глухуватість, застосування трансформацій додавання, експлікації чи описового перекладу: magent contaminateur - розповсюджувач інфекиійного захворювання, $f$ élongation diastolique - фізіологічне розтягнення серия під час діастоли, févacuation alvine - сили спорожнення сечового міхура, $f$ dermatose inflammatoire - запальне захворювання шкіри.

Модель Nom + Nom, що складається 3 двох іменників, один із яких залежить від іншого, які можуть поєднуватися за допомогою прийменників $d e$ та $\grave{a}$ тощо, при перекладі демонструє тенденцію до зміни структури на Adjectif + Nom: $m$ bassinet du rein - ниркова миска, groupe m contrôle - контрольна група.

При перекладі двокомпонентних термінів, як правило, зберігається прагматичний потенціал термінів, оскільки більшість із них відтворюється шляхом калькування.

Трикомпонентні терміни містять додаткову уточнювальну інформацію стосовно певного явища чи поняття, яка виражається найчастіше за допомогою додаткового прикметника, прийменники ж $\epsilon$ додатковим засобом передачі семантичних зв'язків між компонентами. Зазначені аналітичні сполуки представлені головним чином такими моделями:

- Nom + Adjectif + Adjectif ( $f$ bursite villonodulaire hémopigmentée, $m$ cancer cervical rare, $m$ oeil kystique congénital, $m$ oedème maculaire familial, fomodysplasie autosomique récessive);

${ }^{22}$ Гаращенко Л.Б. Аналітичні терміни загальнотехнічної галузі. Вісн. Нац. ун-my «Львів. політехніка». 2012. № 733. С. 96-100. 
- Nom + préposition + Nom + préposition + Nom $(f$ ostéochondrite des épiphyses des phalanges, $m$ enzyme de conversion de l'angiotensine, $m$ léiomyosarcome du col de l'utérus);

- Nom + Adjectif + préposition + Nom (f cachexie diencéphalique de Russel, $m$ essais cliniques des médicaments, $f$ lipodystrophie isolée du mésentère, f calcification cérébrale type Rajab);

- Nom + préposition + Nom + Adjectif ( $m$ carcinome à cellules caliciformes, $f$ expression d'informations hériditaires, $f$ laminopathie avec neuropathie périférique, $f$ lissencéphalie avec hypoplasie cérébelleuse, $f$ dose de rayonnement absorbée, $m$ scléromyxoedème sans gammopathie monoclonale).

Трикомпонентні медичні терміни перекладаються шляхом підбору еквівалента, що супроводжується зміною моделі українського терміна чи порядку комбінації його компонентів: m accident ischémique transitoire - транзиторна ішемічна атака, m ехатеп cytobactériologique d'un crachat - мікроскопічне дослідження мокроти, f fibre тиsculaire lisse - гладке м'язове волокно, $m$ lupus érythémateux disséminé системний червоний вовчак.

Наприклад, комбінація Nom + Adjectif + Adjectif: $f$ coagulation intravasculaire disséminée - синдром дисемінованого внутрішньосудинного згортання відтворюється чотирикомпонентним терміном шляхом трансформації додавання; $f$ pl lipoprotéines de haute densité - ліпопротеїди високої щільності - у процесі перекладу українською мовою застосовується прийом калькування, $m$ inhibiteur de l'enzyme de conversion - iнгібітор ангіотензинутворювального ферменту - структура Nom + Nom + Nom зазнала змін у мові перекладу: Nom + Adjectif + Nom.

Низка трикомпонентних термінів відтворюється шляхом додавання, конкретизації чи експлікації: $m$ cytodiagnostic urinaire sur culot діагностичне ичттологічне дослідження сечових шляхів на основі сечового осаду; m anévrisme d'aorte abdominale - аневризма черевного відділу аорти, $f$ transfusion de culot globulaire - переливання еритроцитарної й лейкоцитарної маси; f élongation-dérotation-flexionкорегувальний гіпсовий корсет, щзо використовується при сколіозі. Отже, трикомпонентні фармацевтичні терміни в більшості випадків перекладаються шляхом застосування калькування, транскрипції, підбором відповідного українського еквівалента й за допомогою описового перекладу.

Серед чотирикомпонентних термінів домінують такі моделі, які найчастіше містять прийменники для вираження додаткових семантичних зв'язків між елементами сполуки: 
- Nom + préposition + Nom + préposition + Nom + préposition + Nom ( $m$ trouble de la synthèse des phospholipides et acides);

- Nom + préposition + Nom + préposition + Nom + Adjectif ( $f$ spasticité de l'enfant avec une hyperglycémie non cétosique);

- Nom + préposition + Adjectif + préposition + Nom + Adjectif ( $m$ lipome associé à une dysraphie neurospinale, $f$ pérméabilité membranaire du filtre rénal, fsclérodermie systémique sans sclérose cutanée, $f$ surdité neurosensorielle avec cardiomyopathie dilatée, $m$ syndrome artériel du défilé thoracique);

$-\mathrm{Nom}+\mathrm{Nom}+$ Adjectif + Adjectif ( $m$ sarcome des cellules réticulaires interdigitées, $m$ syndrome d'activation mastocytaire monoclonal);

- Nom + Adjectif + Adjectif + Adjectif ( $f$ calcinose tumorale normophospha-témique familale, $f$ séquestration pulmonaire congénitale extralobaire, $f$ sténose subaortique fibromusculaire modérée).

У процесі перекладу термінів, що містять чотири компоненти, зазвичай зберігається кількість складників, змінюється лише порядок їх уживання відповідно до норм цільової мови:

- Nom + Adjectif + Adjectif + Adjectif: $f$ calcification artérielle généralisée infantile - Adjectif + Adjectif + Adjectif + Nom: генералізована інфантильна артеріальна кальцифікаиія;

- Nom + Adjectif + prép + Nom + Adjectif: $f$ cytopénie réfractaire avec dysplasie multilignée - Adjectif + Nom + prép + Adjectif + Nom: рефрактерна цитопенія з мультилінійною дисплазією. У певних випадках спостерігається також зміна кількості елементів моделі при перекладі:

- f maladie inflammatoire chronique de l'intestin - хронічне запалення кишківника - фр.Nom + Adjectif + Adjectif + prép + Nom - укр. Adjectif + Nom + Nom;

-f héparines de bas poids moléculaire - низькомолекулярні гепарини фp.Nom + prép + Adjectif + Nom + Adjectif - укр.Adjectif + Nom.

П'яти- та шестикомпонентні термінологічні сполуки медичної галузі представлені великою кількістю моделей, що мають субстантивні й ад'єктивні зв'язки. Головним чином вони утворюються шляхом розширення двох-, трьох- чи чотирикомпонентних терміносполучень відповідно до структур зазначених вище моделей: $f$ lipodystrophie par déficit en facteurs de croissance peptidiques, fsusceptibilité aux effets indésirables graves de la mercaptopurine, f syndactylie mésoaxiale synostosique avec réduction phalangienne.

Аналітичні медичні термінологічні сполуки, як й інші науковотехнічні терміни, що мають п'ять і більше компонентів, у процесі 
вживання мають тенденцію до скорочення шляхом опущення певних елементів ${ }^{23}$.

Отже, виходячи із зазначеного вище, доходимо висновку, що франкомовні медичні бінарні та багатокомпонентні терміни відтворюються в українському перекладі головним чином за допомогою відповідного еквівалента шляхом калькування чи експлікації.

\section{ВИСНОВКИ}

Дослідження лінгвістичних характеристик франкомовних медичних текстів сприяє виявленню передумов та ефективних підходів до здійснення якісного галузевого перекладу й реалізації міжкультурного спілкування вітчизняних і зарубіжних фахівців галузі охорони здоров'я.

Особливостями лексико-семантичного рівня зазначених текстів $є$ їх насиченість спеціальними термінами, які характеризуються стилістичною нейтральністю, наявністю дефініції, стислістю й точністю семантики. Терміни медичної галузі відрізняються своє специфікою 3 погляду дериваційного, структурно-семантичного та стилістичного аспектів. Установлено, що значна частка термінів має в складі афікси та кореневі морфеми латинського і грецького походження, розуміння етимології яких є запорукою здійснення якісного перекладу фахових текстів. Поділ термінологічних сполук на групи відповідно до різних критеріїв дає змогу комплексно проаналізувати термінологічну систему медичної галузі в сукупності ієрархічних зв'язків між ії елементами.

У результаті дослідження виокремлено три групи медичних термінів відповідно до сфери застосування: загальнонаукові, що формують загальнопоняттєву систему різних наукових напрямів, міжгалузеві терміни, використання яких не обмежуюється суміжними галузями, i вузькоспеціалізовані термінологічні одиниці. Відповідно до об'єкта найменування, виділено такі термінологічні підсистеми, як-от: анатомічна, клінічна, адміністративна, фармацевтична тощо, терміни кожної 3 яких мають свої дериваційні, формально-структурні та семантичні особливості. Утворенню французьких медичних термінів властива як синтетична, так й аналітична деривація. Синтетичні способи утворення термінів забезпечують точність, універсальність і лаконічність терміна, тоді як аналітичні форми допомагають конкретизувати, уточнити поняття, надати певну додаткову характеристику об'єкта чи вказівку на його ознаку. Серед морфологічних способів словотвору французької медичної термінології переважають афіксація та основоскладання. У межах аналітичних термінів спостерігається

${ }^{23}$ Гаращенко Л.Б. Аналітичні терміни загальнотехнічної галузі. Вісн. Нац. ун-ту «Львів. політехніка». 2012. № 733. С. 96-100. 
домінування бінарних сполук 3 атрибутивним підрядним зв'язком. Аналіз особливостей відтворення в українському перекладі структурносемантичних характеристик франкомовних синтетичних та аналітичних термінів дав змогу виділити такі найчастотніші прийоми й перекладацькі трансформації, як транслітерація, калькування, пошук відповідного еквівалента, описовий переклад.

Перспективу подальших наукових розвідок убачаємо в аналізі лінгвопрагматичних аспектів перекладу франкомовних медичних текстів українською мовою.

\section{АНОТАЦІЯ}

Статтю присвячено актуальному питанню аналізу мовних характеристик франкомовних медичних текстів, зокрема структурносемантичних особливостей медичної термінології, що $є$ важливою передумовою здійснення адекватного галузевого перекладу. Медична термінологія $є$ специфічним прошарком лексики, класифікаційний підхід до вивчення якої допомагає усвідомити термінологічну парадигму галузі охорони здоров'я. У результаті дослідження здійснено поділ термінів на групи відповідно до таких критеріїв, як-от: сфера застосування та характеристики об'єкта, визначено термінологічні підсистеми медичної галузі шляхом об'єднання термінології в лексико-семантичні групи. Окреслено дериваційний потенціал синтетичних та аналітичних франкомовних медичних термінів. Здійснено аналіз морфологічних i синтаксичних засобів творення нових термінологічних одиниць. Визначено групи бінарних моделей відповідно до характеристик їх компонентів, установлено, що найпоширенішою структурою $є$ атрибутивні сполуки 3 підрядним зв'язком. Досліджено засоби відтворення в українському перекладі структурно-семантичних особливостей франкомовних медичних термінів.

\section{ЛІТЕРАТУРА}

1. Гаращенко Л.Б. Аналітичні терміни загальнотехнічної галузі. Вісн. Нац. ун-ту «Львів. політехніка». 2012. № 733. С. 96-100.

2. Гринев-Гриневич С.В. Терминоведение. Москва : Издательский центр «Академия», 2008. 304 с.

3. Деркач Л.М. Актуальні проблеми науково-технічного перекладу. Донецьк : Національний гірничий ун-т, 2007. 257 с.

4. Ильина Н.В. Особенности перевода медицинской терминологии. Методологія та практика лінгвістичної підготовки іноземних студентів : збірник матеріалів Міжвузівської науково-практичної конференції. Харків, 2012. С. 67-68.

5. Марченко В.С. Основні способи термінотворення (на матеріалі буд. термінології). Культура слова. 1980. Вип. 18. С. 36-40. 
6. Могилевский Р.И. О некоторых специфических функциях аббревиатур. Пермь : Изд-во ПГУ, 1999. С. 60-64.

7. Непийвода Н.Ф. Вираження атрибутивних відношень у терміні. Науково-технічний прогрес і проблеми термінології : тези доп. Респ. конф. Київ, 1980. С. 134.

8. Полюк І.С., Бондар Л.В. Особливості перекладу текстів різних стилів. Французька мова. Київ : НТУУ «КПІ», 2011. 396 с

9. Синельников Ю.Г., Подорванова Я.С. Метафора как средство образования медицинских терминов (на материале французской прессы). Научные ведомости Белгородского гос. ун-та. Серия «Гуманитарные науки». 2014. № 6 (177). Вып. 21. С. 116-121.

10. Ракшанова Г.Ф. Система дериваційних засобів сучасної науковотехнічної термінології (когнітивно-номінативний аспект) : автореф. дис. ... канд. філол. наук : 10.02.01. Київ, 2004. 20 с.

11. Солнцев Е.М. Перевод медицинских текстов: к вопросу о соотношении общих и частных проблем. Москва : ИПК МГЛУ «Рема», 2010. URL: http: // www.thinkaloud.ru/science/solnts-med.pdf (дата звернення: 25.08.2020).

12. Kühnel W. Atlas de poche d'histologie: Cytologie, histologie et anatomie microscopique. Paris : Edition Flammarion, 2003. 534 p.

13. Rouleau M. La traduction médicale: une approche méthodique. Brossard (Québec) : Linguatech, 1994. 326 p.

\section{Information about the authors:}

Bondar L. V.,

Candidate of Pedagogical Sciences, Associate Professor, Associate Professor at the Department of French Theory,

Practice and Translation

National Technical University of Ukraine "Igor Sikorsky Kyiv Polytechnic Institute" 37, Peremohy avenue, Kyiv, 03056, Ukraine

Shkolyar L. V., Candidate of Pedagogical Sciences, Associate Professor, Associate Professor at the Department of French Theory,

Practice and Translation

National Technical University of Ukraine "Igor Sikorsky Kyiv Polytechnic Institute" 37, Peremohy avenue, Kyiv, 03056, Ukraine 